\section{Causes of the United States Floods}

THE unprecedented floods of the Ohio River in January of this year are the subject of a paper by Prof. C. F. Brooks and Major A. H. Thiessen in the Geographical Review of April. Floods may occur in the eastern United States at any time of the year, for there is always an extensive warm water surface near by to provide great volumes of water vapour, and not far distant are cold surfaces to furnish moving wedges of cold air to elevate the tropical air. Outstanding floods, however, occur only where a persistent high pressure area over the western Atlantic sends air currents inland for days in succession, and a winter high pressure area over the central or northern interior of the United States sends cold air southward or south-eastward. Along the front between the masses of polar air and the tropical air continuous ascent of the warmer air occurs with resultant heavy rains. In an ascent of two miles, three quarters of the water vapour in the warm air is precipitated. The authors calculate that a mass of air, nearly saturated at $77^{\circ} \mathrm{F}$. over the Caribbean Sea, chilled over land in middle latitudes to $68^{\circ} \mathrm{F}$., would contain about 80,000 tons of water vapour for every square mile of surface. If this were forced upward to a height of two miles the rainfall would be 0.8 inches. This would probably occur in one day with wind at a velocity of four to eight miles an hour. Since the average speed of the tropical air mass is 30.40 miles an hour, it is easy to understand the occurrence of torrential rains of some five inches a day.

\section{The Czechoslovak National Research Council}

THE Czechoslovak National Research Council, which is affiliated to the International Council of Scientific Unions, was founded in 1924 originally with ten (now twenty) sections and with a membership limited to two hundred. It includes all branches of science as well as mathematics, medicine and philology, and at first its activities were mainly concerned with establishing good international scientific relations. To-day, its aims are specially directed towards the promotion and financial support of scientific research in general. In this it has the co-operation of the Czechoslovak Ministry of Education, and its work assumed considerable importance when the economic depression began to impede both international relations and the prosecution of pure researches. In 1935, a Masaryk Foundation for the endowment of scientific work was established with an initial capital of three million crowns (about $£ 25,000$ at the time) to ensure that adequate financial assistance was available for the purchase of apparatus needed for research purposes, for the publication of scientific books and memoirs and for travelling scholarships. These funds of the Czechoslovak Research Council are intended especially for the support of promising young men of science in Czechoslovakia, irrespective of their nationality or creed. In the annual report for 1936 it is mentioned that the Council awarded travel fellowships to ten students and granted 193,000 crowns (about $£ 1,400$ ) towards the publication of some tifty noteworthy scientific works and for acquiring apparatus. During 1937, thirteen students have been sent abroad to continue their studies. The president of the Council is Prof. B. Nermec, and the general secretary, Prof. F. Ulrich, whose address is Prague II, Albertov 6.

\section{Solar Heaters in California}

The large amount of sunshine available in California during the summer has led to the extensive use of solar water-heating apparatus for domestic purposes, and a detailed account of their construction and use is given by Prof. F. A. Brooks of the Berkeley Agricultural Experiment Station in Bulletin 602 of the College of Agriculture. The solar absorber consists of a zigzag pipe in a glass-covered, thermally insulated box placed on a sloping roof facing south, in front of attic windows so that the glass may be readily cleaned. An insulated pipe leads from the top of it to the top of an insulated hot-water tank in the attic roof and another pipe from the bottom of the absorber to the bottom of the tank. In the winter the solar absorber is supplemented by a coil in the range connected to the tank in the same way. The useful life of such an installation is fifteen years, and the cost per 1,000 British thermal units of solar heat absorbed is about one ninth of a cent.

\section{Prof. M. N. Saha, F.R.S.}

WE have received a pamphlet summarizing the scientific work of Prof. M. N. Saha, who, as indicated in NATURE of March 13, has recently been elected president of the National Institute of Sciences of India for the current year. In addition to his theory of stellar spectra, which in fact was begun in India before he came to England, Prof. Saha has made experimental researches with the object of confirming the theory and has produced papers on selective radiation pressure, active nitrogen, spectroscopy and atomic and molecular structure, the colours of inorganic salts, thermodynamics, Dirac's theory of the electron, and upper atmospheric phenomena. He has also written treatises on heat and on modern physics, and has promoted much research on mole. cular spectra by students working under him.

\section{Association of Teachers in Technical Institutions}

THE twenty-eighth annual ('onference of the Association of Teachers in Technical Institutions will be held at Coventry on Saturday May 15-18 under the presidency of Mr. W. E. Park. All meetings will be held in the Technical College, Coventry. Resolutions to be discussed by the Conference comprise the following : courses of training for technical teachers; tenure of university scholarships; leave of absence for technical teachers; assistance to teachers attend. ing short courses of the Board of Education; cooperation in technical education; the Factory Act; day technical classes. Further information can be obtained from the Secretary, A.T.T.I., 29 Gordon Square, London, W.C.1. 